\title{
EFFECTIVENESS OF METARHIZIUM ANISOPLIAE AGAINST IMMATURE STAGES OF ANASTREPHA FRATERCULUS FRUITFLY (DIPTERA : TEPHRITIDAE)
}

\author{
Ricardo Henry Rodrigues Destéfanoํㅜ Ivanira José Bechara²; Claudio Luiz Messias ${ }^{1 *}$; \\ Aquiles Eugênico Piedrabuena ${ }^{1 \dagger}$
}

\begin{abstract}
${ }^{1}$ Departamento de Genética e Evolução, Instituto de Biologia, Universidade Estadual de Campinas, Campinas, SP, Brasil; ${ }^{2}$ Departamento de Histologia e Embriologia, Instituto de Biologia, Universidade Estadual de Campinas, Campinas, SP, Brasil
\end{abstract}

Submitted: March 15, 2004; Returned to authors for corrections: August 19, 2004; Approved: March 10, 2005

\begin{abstract}
The study evaluated the effectiveness of Metarhizium anisopliae var. anisopliae (Hyphomycetes : Moniliales) strain E9, isolated from the pasture spittlebug Deois flavopicta (Hemiptera : Cercopidae), against larvae, prepupae and pupae stage and emergent adults of Anastrepha fraterculus, the South American fruitfly. The bioassay was carried out simulating field conditions, on autoclaved (AS) and non-autoclaved (NAS) soil from typical citrus orchards in the State of São Paulo, Southeastern region of Brazil. Various concentrations of conidia were incorporated into the soil the mortality, calculated based on the percentage of adult emergence, was $86 \%$ for the highest conidia concentrations: $2.52 \times 10^{10}$ for AS and $2.52 \times 10^{10}$ for NAS. The lethal concentration ( $\mathrm{LC}_{50}$ ), expressed as conidia concentration, was $8.44 \times 10^{9}$ conidia/g of soil (S) for AS and 12.23 x $10^{9}$ conidia/g of soil for NAS.
\end{abstract}

Key words: microbial control, Metarhizium anisopliae, Anastrepha fraterculus, fruitfly, bioassay

\section{INTRODUCTION}

Tephritids fruitflies of the genus Anastrepha Schiner, 1868 (South American fruitflies) and Ceratitis capitata Wiedemann, 1848 (Mediterranean fruitflies) represent a group of pests of economic importance for the fruit-growing industry worldwide. Approximately 300 species belonging to 41 botanic families have been reported to be hosts of these tephritids (15). Among the most intensively attacked species are guava, peaches, pears, apples, melons, plums, nectarines, mangoes, oranges, and grapes. Due to their wide geographic distribution in tropical, subtropical and temperate climates, these pests also attack wild fruit varieties.

In Brazil, fruitflies of the genus Anastrepha, especially $A$. fraterculus, the South American fly, and A. obliqua, have the widest geographic distribution (13). These two species, together with $A$. sororcula and $A$. grandis, are considered quarantine species by protection agencies from various countries (14).
These insects have been controlled in fruits using traditional chemical products although efficient efforts are under way for the development of an Integrated Management Program using biological control agents $(11,20,21)$, in addition to attempts involving the use of bioregulators such as gibberellic acid (10). Entomopathogenic agents such as fungi, bacteria, viruses and nematodes have been reported to infect tephritids (2). However, quantitative studies of the action of predators and of entomopathogenic agents in terms of fruitfly mortality are not as frequent as studies of the action of parasitoids (6). Among the entomopathogenic fungus cited in the literature are Paecilomyces fumosoroseus and Beauveria bassiana (4). Studies by Garcia et al. $(8,9)$ have shown the virulence of Metarhizium anisopliae on larvae, pupae and adults of Ceratitis capitata.

In the present investigation we evaluated the susceptibility of the species A. fraterculus to Metarhizium anisopliae, an entomopathogenic hyphomycete, under conditions of bioassay in soil, since under field conditions the larvae, after developing *Corresponding Author. Mailing address: Departamento de Genética e Evolução, Instituto de Biologia, Universidade Estadual de Campinas, Caixa
Postal 6109. 13083-970, Campinas, SP, Brasil. Tel.: (+5519) 3788-6233, Fax: (+5519) 3788-6235. E-mail: cmessias@unicamp.br. ‘n memoria. 
in the fruit, fall to the ground and penetrate the soil, later transforming into pupae and emerging as adults (19). The use of $M$. anisopliae is justified by the results already obtained against $C$. capitata and by the fact that it is currently sold as an important biological control agent for various insect species in many countries such as Colombia, Australia and the United States of America. Particularly in Brazil, more than 1,000,000 ha have been treated for the control of the leaf spittlebug Mahanarva posticata, and the root spittlebug $M$. fimbriolata (Hemiptera : Cercopidae) in sugar cane and spittlebug in pasture grasses (12). In addition, it should also be mentioned that importers require "in natura" fruits, specially those without pesticides residues (5).

\section{MATERIALS AND METHODS}

\section{Strain used and inoculum production}

We used strain $\mathrm{E}_{9}$ of M. anisopliae var. anisopliae, isolated from Deois flavopicta, the pasture spittlebug maintained in the germplasm bank of the Department of Genetics and Evolution, Biology Institute, UNICAMP, and reisolated from A. fraterculus larvae. Conidia of the $\mathrm{E}_{9}$ reisolate of $A$. fraterculus were obtained from a culture grown for 10 days on rice medium containing 100 $\mathrm{g}$ rice and $80 \mathrm{~mL}$ water in Erlenmeyer flasks autoclaved at $1 \mathrm{~atm}$ for 20 minutes. At the end of culture period, the conidia were collected by scraping the surface of the culture medium with the aid of a sterilized spatula and pressed through a sterilized $1.25 \mu \mathrm{m}$ opening sieve. For the preparation of the desired concentration, the conidia were counted with a hemocytometer. The viability was determined in relation to the percentage of germination in minimal medium (MM) (NaNO3 6.0g, $\mathrm{KCl} 0.52 \mathrm{~g}$, $\mathrm{MgSO} 4.7 \mathrm{H} 2 \mathrm{O}, 0.52 \mathrm{~g}$, KH2PO4 $1.52 \mathrm{~g}$, glucose $10.0 \mathrm{~g}$ and trace of $\mathrm{FeSO} 4.7 \mathrm{H} 2 \mathrm{O}$ and $\mathrm{ZnSO} 4$ both at the concentration of $1 \%$ and $15 \mathrm{~g}$ agar per litre $\mathrm{pH}$ 6.9) by counting 500 germinated and non-germinated conidia using a phase contrast microscope 15 hours after inoculation at $28^{\circ} \mathrm{C}$. The doses, expressed as conidia concentration (con) per gram (g) of soil (S), were as follows: $\left(d_{1}\right)$ $2.52 \times 10^{8} \mathrm{con} / \mathrm{gS}, \mathrm{d}_{2}=2.52 \times 10^{9} \mathrm{con} / \mathrm{gS}$, and $\mathrm{d}_{3}=2.52 \times 10^{10} \mathrm{con} / \mathrm{gS}$.

\section{Collection of larvae of the host insect}

The 13 days old larvae of $A$. fraterculus at were obtained from laboratory population using papaya (Carica papaya Caricaceae) as oviposition substrate.

\section{Conidia longevity under soil conditions}

Longevity was estimated on the basis of percent of conidia germination calculated as mentioned above in autoclaved (AS) and non-autoclaved (NAS) soil maintained under the same experimental conditions as used in the bioassay and inoculated with $10^{7}$ conidia/g S. Longevity was evaluated over a period of 28 days using weekly 3 samples of $5 \mathrm{~g}$ of soil each. The samples were transferred to Erlenmeyer flasks containing $300 \mathrm{~mL}$ sterilized distilled water and $5 \mathrm{~mL} 0.1 \%$ Tween 80 and shaken at $150 \mathrm{rpm}$ for 120 minutes. After this time, $0.1 \mathrm{~mL}$ aliquots of the supernatant were removed and plated onto dodine medium (3) modified by the addition of $15.0 \mathrm{~g}$ rice cream and $1 \mathrm{mg}$ streptomycin per $\mathrm{mL}$ of culture medium. The plates were incubated for $96 \mathrm{~h}$ at $28^{\circ} \mathrm{C}$ for viability evaluation by counting the colony forming units (cfu).

\section{Bioassay preparation}

The assay was carried out in $500 \mathrm{~mL} 7.5 \mathrm{~cm}$ deep plastic cups with a mouth diameter of $8.5 \mathrm{~cm}$, containing $400 \mathrm{~g}$ of air-dried dirt red latossol typical of the citrus orchards region in the State of São Paulo, in two different preparations, one containing AS and the other NAS and moisturized to $75 \%$ humidity, obtained by determination of dry weight and addition of deionized sterile water. Different conidia concentration were incorporated into the soil as cited previously, and 50 larvae in the prepupal phase (13 days old) were then released on the soil surface for each of three replicates in the different treatments. Three replicates without conidia were maintained in each treatment as controls. The preparations were maintained under environmental conditions with humidity of approximately $75 \%$ and temperature of $28^{\circ} \mathrm{C}$.

The effect of treatment on the emerging population in relation to the control was evaluated daily after the emergence of the first adult. The infection confirmation by the fungus was done by collecting and carefully washing dead hosts (larvae, pupae and adults) three times in $2.5 \%(\mathrm{v} / \mathrm{v})$ sodium hypochloride, and $0.1 \%(\mathrm{v} / \mathrm{v})$ Tween 80 solution for 3 minutes and three times in $0.85 \% \mathrm{NaCl}$ solution. After being washed, they were transfered to a moisturized chamber and incubated at $28^{\circ} \mathrm{C}$, until development of the propagulus of the fungus on the cadaver. The median lethal concentration $\left(\mathrm{LC}_{50}\right)$ was calculated by the probit method (7) with correction for the natural population reduction in the control (1).

\section{RESULTS AND DISCUSSION}

Under the studied conditions, the developmental cycle of the host insect, consisting of the larvae at the prepupal stages and pupae until adult emergence (considered as the beginning of emergence), lasted approximately 12 to 17 days after larval deposition on the soil surface, when the environmental temperature was about $28^{\circ} \mathrm{C}$ and humidity about $75 \%$. The prepupal larval period lasted up to $32 \mathrm{~h}$, with a concentration around $24 \mathrm{~h}$ for both AS and NAS. These results are in agreement with data obtained by Orlando and Sampaio (16) who reported a cycle of 10 to 20 days. Thus, no type of antibiosis caused by biotic factor of the microbial population existing in NAS or by other measurable abiotic factor was observed during the experiment. Despite the relatively long developmental cycle of the host, the period of exposure, which is the period when the conidia have the opportunity for adherence and penetration through the integument of the larval stage, was about 24 hours 
as observed by Bechara et al. (in preparation). This phase corresponds to adherence and penetration starting with conidia contact with the cuticle, through germination and the presence or absence of differentiation into apressoria, which, according to Roberts et al. (17), are initial events in the mechanism of infection by entomopathogenic fungi. The longevity of the conidia in the soil, (germinative capacity of the conidia) ranged from $94.06 \%$ for NAS and $94.70 \%$ for AS at the beginning of the experiment to $31 \%$ on the 28 th day (Table 1) for both NAS and AS. Based on the data concerning survival of conidia on AS and NAS (Table 1), normalized by angular transformation $\alpha^{0}=\operatorname{arc} \sin$ $\sqrt{\mathrm{p}}$, where $\mathrm{p}=(\% / 100)$, we performed the analysis of variance (Table 2). The ANOVA (NAS and AS) did not show significant differences between AS and NAS. Thus, the conidia exhibited the potential for host infection under the bioassay conditions. The presence of viable conidia throughout the experiment indicates infection not only of larvae, but also of pupae and emerging adults. As observed by soil inspection this appears to have occurred at the end of the bioassay, even though this infection probably occurred during the larval or prepupal or during the pupation stage and was manifested by the fungus growing on cadaver and dead pupae, as well as on dead emergents adults. The mortality confirmation was done by the reisolation of the fungus from the host after being carefully

Table 1. Viability of reisolated conidia of M. anisopliae strain E9 from soil (NAS and AS) during bioassays expressed as colony forming units (CFUs) on dodine medium.

\begin{tabular}{ccc}
\hline \multirow{2}{*}{ Days since inoculation } & \multicolumn{2}{c}{$\%$ Viability* } \\
\cline { 2 - 3 } & NAS & AS \\
\hline 0 & 94.06 & 94.70 \\
7 & 81.90 & 81.03 \\
14 & 59.20 & 57.07 \\
21 & 49.20 & 50.33 \\
28 & 31.00 & 31.00 \\
\hline
\end{tabular}

* values are means of three replicates

Table 2. The ANOVA for conidia viability of $M$. anisopliae strain E9 on Dodine media expresed as percent of conidia reisolete from NAS and AS based on data from Table 1, normalized by angular transformation $\alpha^{0}=\operatorname{arc} \sin \sqrt{ }$, where $\mathrm{p}=(\% / 100)$.

\begin{tabular}{lcccc}
\hline Sources of variation & GL & F & P & NS \\
\hline Soil (NAS and AS) & 1 & 0.6667 & 0.424 & NS \\
Days of inoculation & 4 & $3,920.68$ & 0.000 & $*$ \\
Soil X Days of inoculation & 4 & 2.27 & 0.098 & NS \\
Residue & 20 & QMR $=0.4246$ & \\
\hline
\end{tabular}

surface washed as mentioned in bioassay preparation. Figs. 1a, $\mathrm{b}$ and $\mathrm{c}$, show the development of the fungus in these stages; however, it was not an objective of the present study to evaluate mortality during the different developmental stages but rather to assess the reduction of adult emergence, considered as the additive result of a total lethality action for the various stages. Thus, in the preparation of the bioassays we opted for the incorporation of conidia into the entire soil because of the typical behavior of the larvae, which after falling on the ground, burrow into the soil to different depths, usually ranging from $2 \mathrm{~cm}$ to $10.0 \mathrm{~cm}$ (18), and more often from 2 to $6 \mathrm{~cm}$. In this movement during the prepupal phase, conidia removal may occur if the conidia were only placed on the surface. Also, the conidia may be exposed to other unfavorable abiotic factors with a consequent reduction in inoculum potential. However, surface application would be much easier and therefore this possibility should be considered when evaluating applicability in the field.

Evaluation of the emerging adult population in relation to the control permitted the determination of the $\mathrm{LC}_{50}$ values both in AS and NAS using probit analysis (7) with correction for natural mortality in the control (1).

As can be seen in Fig. 2, the probit lines for AS and NAS did not diverge since their regression coefficients $(b=1.2748$ for AS and $b=1.27736$ for NAS) were quite close. This was not the case for the coordinates of origin which were 6.1091 and 4.6923, respectively, and which presented a $\mathbf{t}$ value of $4.2962<4.303$ for 2. d.f. at the $5 \%$ level of probability when tested. However, this could be considered a significant tendency since the $\mathbf{t}$ probability obtained would be $p=0.052$. In both cases, the chi-square values indicated that the curves fitted since there were no significant differences ( $\mathrm{p}=0.694$ for AS and $\mathrm{p}=0.627$ for NAS).

The $\mathrm{LC}_{50}$ values, although different $\left(8.44 \times 10^{9} \mathrm{con} / \mathrm{gS}\right.$ for AS and $12.23 \times 10^{9} \mathrm{con} / \mathrm{gS}$ for NAS), presented different confidence

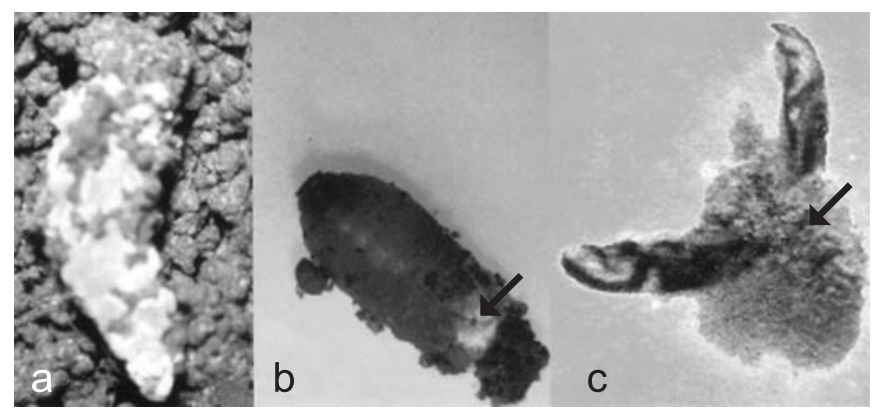

Figure 1. Carcasses of imatures stages and adult of $A$. fraterculus infected with $M$. anisopliae showing mycelial development after infection with conidia incorporated into the soil. (a) larvae, the white color is given by the young mycelial growth; ( b) pupae: mycelium and conidiation growing out from the extremity (arrow) and (c) emergent adult completely covered with mycelia and young conidia (arrow). 
intervals (CI) of $5.15 \times 10^{9} \mathrm{con} / \mathrm{gS}$ to $13.84 \times 10^{9} \mathrm{con} / \mathrm{gS}$ and 7.43 x $10^{9} \mathrm{con} / \mathrm{gS}$ to $20.14 \times 10^{9} \mathrm{con} / \mathrm{gS}$, respectively, which crossed and contained the $\mathrm{LC}_{50}$ for both treatments at their extremes (Fig. 3a). The $\mathrm{LC}_{50}$ value for AS had a lower confidence interval than for NAS, which did not reach $2 / 3$ of the confidence interval for NAS. If the CI for NAS were equal to that for AS, they would not include the $\mathrm{LC}_{50}$. This may be due to a greater heterogeneity possibly occurring in NAS, which would disperse its CI. On the other hand, this is reflected in the calculation of the potency (R) of AS taking NAS as the standard. The potency of AS was R = 1.45 and CI of 0.85 to 2.47 (Fig. 3b) indicates that NAS could be almost identical to AS, perhaps because of its dispersion, with the latter being on average $45 \%$ more potent and reaching a maximum value around $147 \%$ higher. This amplitude of the data is possibly due to the dispersion produced by the number of doses, a fact that could be improved using intermediate doses.

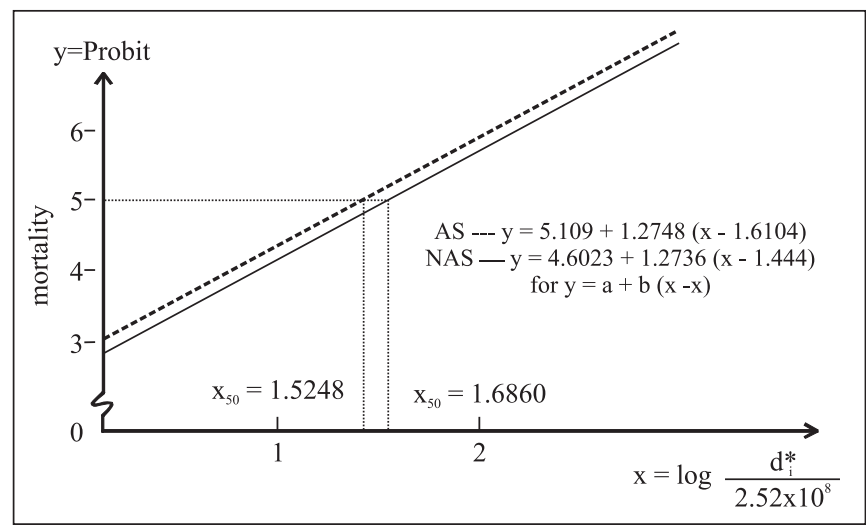

* were corresponds to different doses based on conidia concentration/gS.

Figure 2. Probit curves corrected for mortality (reduction on the emergent adult population) in relation to control.

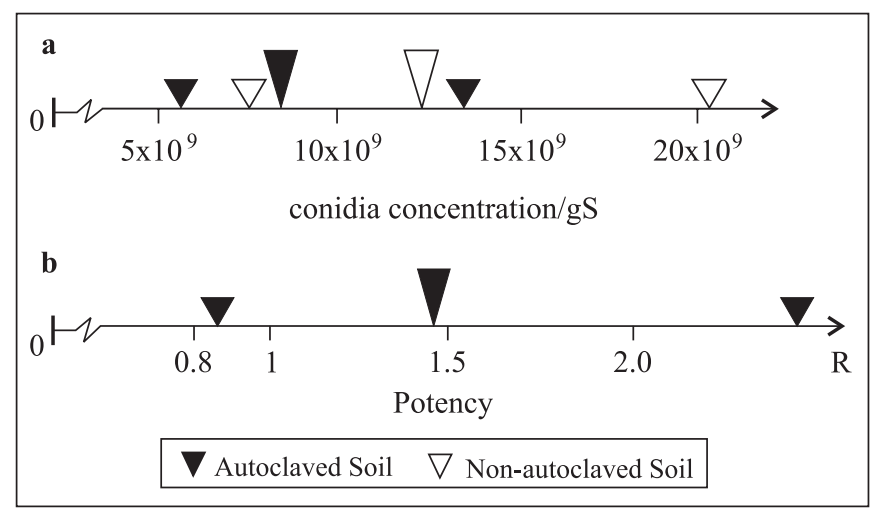

Figure 3. a) LD50 for AS and NAS and its respective confidence intervals; b) Relative Potency $=\mathrm{R}=1.45(0.82-2.42)$. (standard $=$ non-autoclaved soil)
Using a graphic extrapolation (Fig. 4), we may state that a concentration of $2.52 \times 10^{11} \mathrm{con} / \mathrm{gS}$ may produce mortality rates of $97 \%$ and $95 \%$ for AS and NAS, respectively. However, we obtained respective mortality rates of 70 and $67 \%$ with the doses of $2.52 \times 10^{10} \mathrm{con} / \mathrm{gS}$ which is not negligible as a control and which potentiates the large-scale use of the inoculum. It is important to mention that $50 \mathrm{~g}$ of rice media yielded $1 \mathrm{~g}$ of conidia having approximately $2.68 \times 10^{10}$ viable conidia.

The cumulative emergence data were converted to percentages of the total number of larvae used for each treatment (150 larvae) and are reported without the 1st dose since the results of the latter were closely similar to those of the controls (Fig. 5). Cumulative emergence increased in a linear manner in both controls, reaching a maximum of $70 \%$ on the 6th day. With the 2nd dose there was no emergence on the first day (in relation to the beginning of emergence) in AS, and the curve soon took on an irregular sigmoidal shape until a maximum of 54\% emergence was reached on the sixth day. With respect to NAS, emergence started on the first day at $2 \%$, rapidly increasing to $58 \%$ on the fifth day and stabilizing at $60 \%$ on the sixth day, in a sigmoidal manner, a value practically parallel to that for AS.

With the $3^{\text {rd }}$ concentration, emergence was the same as obtained with the 2nd concentration on the first day or $0 \%$ for AS and 2\% for NAS, with the curves following a slightly sigmoidal shape and with little difference between them, both reaching maximum emergence on the fifth day at $14 \%$ both at the conidia concentration of $2.52 \times 10^{10}$ for AS and NAS.

These last two results indicate that at these conidia concentrations there was no difference in maximum emergence on the fifth day, a fact possibly due to the death of more sensitive larvae before pupation or to death of adults when emerging from the pupae. Despite these hypotheses, however, it is clear

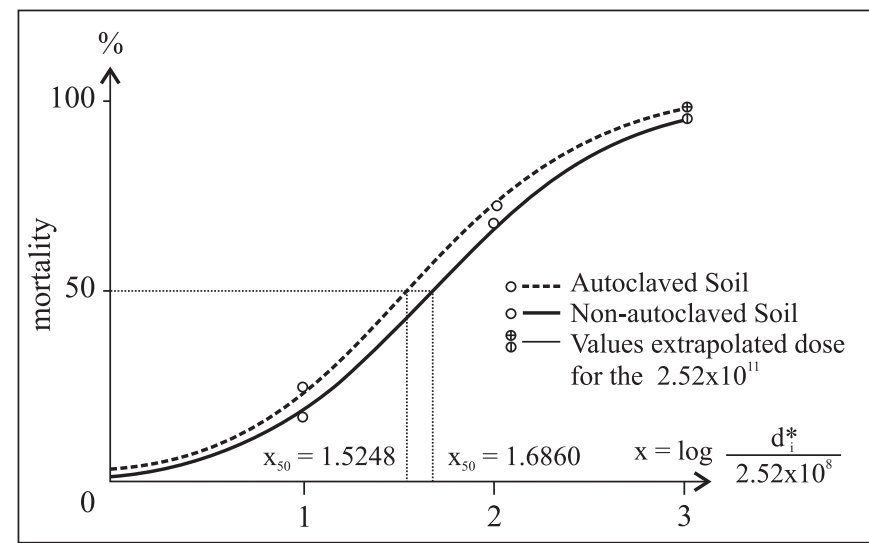

* where di corresponds to the different doses based on conidia concentation/ gS utilized.

Figure 4. Mortality rate corrected in relation to control mortality in autoclaved soil (AS) and non-autoclaved soil (NAS). 


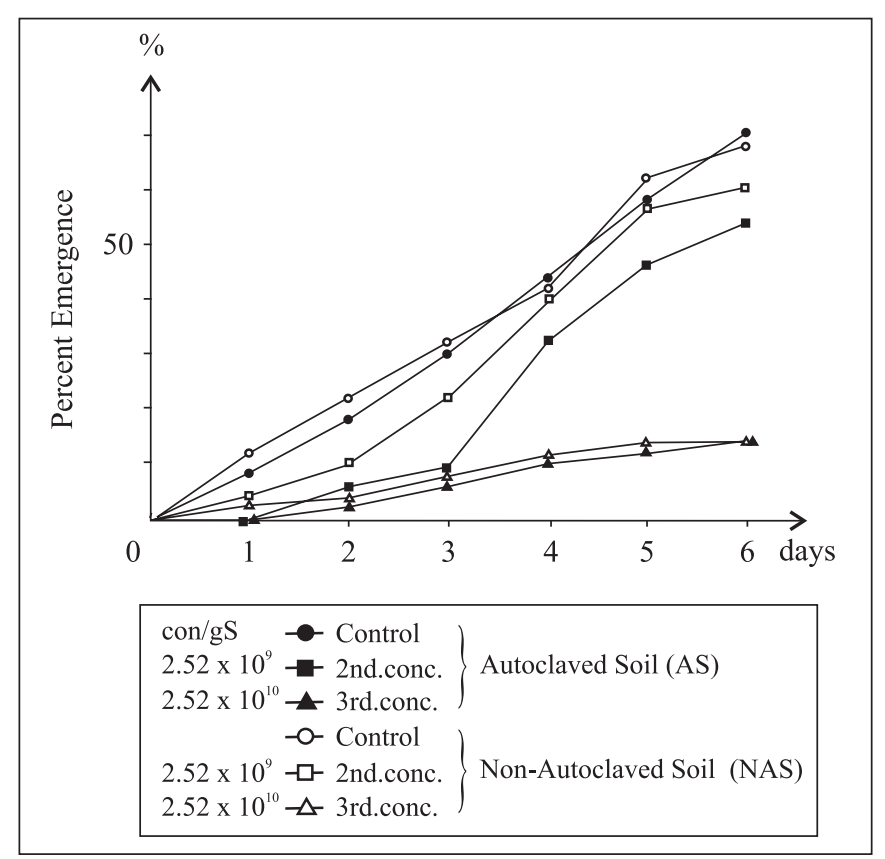

Figure 5. Percent daily adult emergence for the control and $2^{\text {nd }}$ and $3^{\text {rd }}$ conidia concentration (The curve for the $1^{\text {st }}$ conidia concentration is not presented in the figure because it was considerably similar to the control curve) con/gS = conidia per gram of soil; conc. $=$ conidia concentration.

that the effect of the fungus led to an $86 \%$ reduction in population emergence, a fact that recommends its use in field tests as a control agent.

\section{ACKNOWLEDGMENTS}

The authors thank Dr. Donald W. Roberts from Utah State University, Logan-UT.USA for kindly reading the manuscript and valuable criticism and Dr. Vera Nisaka Solferini, from Institute of Biology, State University of Campinas, Campinas-SP.Brazil, for supplying the insects and Conselho Nacional de Desenvolvimento Científico e Tecnológico - CNPq, for financial support.

\section{RESUMO}

\section{Eficácia de Metarhizium anisopliae a estágios imaturos de Anastrepha fraterculus a mosca das frutas (Diptera : Tephritidae)}

O estudo avaliou a eficácia de Metarhizium anisopliae var. anisopliae, (Hyphomycetes : Moniliales) linhagem E9, isolada da cigarrinha das pastagens Deois flavopicta (Hemiptera : Cercopidae), contra larvas, prepupas, pupas e adultos emergentes de Anastreha fraterculus, a mosca Sul Americana das frutas. Os bioensaios foram conduzidos simulando condições de campo em solo autoclavado (AS) e não autoclavado (NAS) de pomares típicos de citros no Estado de São Paulo, sudeste do Brasil. Várias concentrações de conídios foram incorporadas no solo. A mortalidade calculada sobre a porcentagem de adultos emergentes, foi de $86 \%$ para as concentrações mais altas de conídios: 2,52 x $10^{10}$ para AS e 2,52 x $10^{10}$ para NAS. A concentração letal $\left(\mathrm{LC}_{50}\right)$ expressa pela concentração de conídios, foi $8,44 \times 10^{9}$ conídios/g de solo para AS e $12,2 \times 10^{9}$ conídios/g/S para NAS.

Palavras-chave: controle microbiano, Metarhizium anisopliae, Anastrepha fraterculus, mosca-das-frutas, bioensaio

\section{REFERENCES}

1. Abbott, W.S. A method of computing the effectiviness of an insecticide. J. Economics Entomol., 18, 265-267, 1925.

2. Bashiruddin, J.; Martin, J.; Reinganum, C. Queensland fruit fly virus, a probable member of the Piconaviridae. Arch. Vir., 100, 61-74, 1988.

3. Beilharz, V.C.; Parberry, D.G.; Swart, H.J. Dodine: a selective agent for certain soil fungi. Trans. Br. Mycol. Soc., 79, 507-511, 1982.

4. Carneiro, R.M.D.G.; Salles, L.A.B. Patogenicidade de Paecilomyces fumosoroseus, isolado CG 260 sobre larvas de pupas de Anastrepha fraterculus Wied. An. Soc. Entomologica Brasileira, 23, 341-343, 1994.

5. Carvalho, R. da Silva; Nascimento, A.S.; Matrangolo, W.J.R. Controle Biológico In: Malavasi, A.; Zucchi, R.A. Moscas-das-frutas de Importância Econômica no Brasil - Conhecimento Básico e Aplicado. Holo Editora 113 - 117. Ribeirão Preto - SP. Brazil. 2000, p. 113-117.

6. Debouzie, D. Biotic mortality factors in tephritidae populations. In: Robinson, A.S.; G. Hooper (eds). Fruit flies, their biology, natural enemies and control. Elsevier, Amsterdam. 1989, p. 221-227.

7. Finney, D. Probit Analysis, Cambridge. 1971, 333p.

8. Garcia, A.T.E.; Baracho, I.R.; Souza, H.M.L. de; Messias, C.L. Virulência de linhagens mutantes e diplóides de Metarhizium anisopliae, em Ceratitis capitata (Wied.) (Diptera, Tephridiae). Rev. Bras. Ent., 29, 267-270, 1985.

9. Garcia, A.T.E.; Messias, C.L.; Souza, H.M.L. de; Piedrabuena, A.E. Patogenicidade de Metarhizium anisopliae var. anisopliae a Ceratitis capitata (Wied.) (Diptera, Tephritidae). Rev. Bras. Ent., 28, 421424, 1984.

10. Greany, P.D.; McDonald, R.E.; Shaw, P.E.; Schroeder, W.J.; Howards, D.F.; Hatton, T.T.; Davis, P.L.; Rasmussen. Use of gibberellic acid to reduce grapefruit susceptibility to attack by the Caribbean fruit fly Anastrepha suspensa (Diptera: Tephritidae). Trop. Sci., 27, 261270, 1987.

11. Greathead, D.J. Biological Control in the tropics: Present opportunities and future prospects. Insect Sci. Applic., 12, 3-8, 1991.

12. Leite, L.G.; Alves, S.B.; Pereira, R.M. Inseticidas Microbianos. In: Aguayo, G.S.; Gallo, R.H. (eds.). Bases para el manejo racional de inseticidas. Trama Impressores S.A. Chillán. 2003, p. 113-156.

13. Morgante, J.S. Moscas-das-frutas (Diptera: Tephritidae): características biológicas, detecção e controle. SENIR, Boletim Técnico 2, Brasília DF. Brasil, 1991, 19 p.

14. Nascimento, A.S.; Haji, F.N.P.; Caracalho, R.S. Monitoramento de moscas-das-frutas (Tephritidae) no sub-médio São Francisco. 
Congresso Brasileiro de Entomologia, 14, Piracicaba, SP, Brasil. 1993 , p. 607.

15. Norrbom, A.L.; Kim, K.C. A list of the reported host plants of the species of Anastrepha (Diptera: Tephritidae). APHIIS, USDA. 8152, 1988, 114p

16. Orlando, A.; Sampaio, A.S. "Moscas das frutas", notas sobre o reconhecimento e combate. Biológico., 39, 143-150, 1973.

17. Roberts, D.W.; Fuxa, I.R.; Gavgler, R.; Goettel, M.; Jaques, R.; Maddox, J. Use of pathogens in insect control. In: Pimentel, D., (ed.). Handbook of Pests Management in Agriculture. CRC Press Boca Raton, FL. USA. 1991, p. 243-278.

18. Salles, A.B.; Carvalho, F.L.C. Profundidade da localização da pupária de Anastrepha fraterculus (Wied.) (Diptera: Tephritidae) em diferentes condições do solo. Anais da Sociedade Entomológica do Brasil, 22, 299-305, 1993.

19. Salles, L.A.B. Mosca das Frutas, Anastrepha fraterculus (Wied.): Bioecologia e Controle. Pelotas, EMBRAPA/CNPFT, 1991, p. 16.

20. Shuneman, M.A. Manejo integrado de la mosca de la fruta. Trillas, Mexico, 1993, p. 251.

21. Sivinski, J.M.; Calkins, C.O.; Baranowski, R.; Harris, D.; Brambila, J.; Diaz, J.; Burns, R.E.; Holler, T.; Dodson, G. Suppression of a Caribbean fruit fly (Anastrepha suspensa (loew) (Diptera: Tephretidae) population through augmented releases of the parasitoid Diachasmimorpha longicaudata (Ashmead) (Hymenoptera: Braconidae). Biological Control, Florida, 2, 177-185, 1996. 